\title{
Validation of a social entrepreneurial self-efficacy
}

\author{
Radin Siti Aishah Radin A Rahman ${ }^{1}$, Zaidatol Akmaliah Lope Pihie ${ }^{2}$ \\ ${ }^{I}$ Faculty of Education, Universiti Kebangsaan Malaysia \\ ${ }^{2}$ Faculty of Educational Studies, Universiti Putra Malaysia
}

\begin{abstract}
Young generation especially students in Higher Education Institutions (HEI), needs to play a role in accomplishing government initiatives to foster social entrepreneurship culture in Malaysia. They must have an in-depth understanding of the concept before applying it in creating social enterprises. Social entrepreneurship development in this country is still at the beginning stage (General Entrepreneurship Monitor 2009, 2011). However its potential also contributes to sustainable and balanced environment in the community's quality of life. A strong belief in capability and determination must be anchored by the theory of planned behaviour (Ajzen, 1991), which is associated to the theory of cognitive learning (Bandura, 1977). This study focused on self-efficacy construct towards a strong belief in social goal and sustainability in handling the problem of marginalised group through social entrepreneurial activities. The objective of this survey was to test the validity of social entrepreneurial self-efficacy (SESE) instrument. Questionnaires were distributed to 321 students who were members of ENACTUS club in HEI all over Malaysia to gather their perception towards this study. This instrument was adapted from social entrepreneurial self-efficacy by Urban (2013) and was analysed using confirmatory factor analysis (CFA). The result found that the loading factor was more than 0.70 and fit indices including goodness-of-fit of Relative Chi-Square was less than 0.50 with CFI, GFI, and TLI values were greater than 0.90 and RMSEA value was less than 0.08. Convergent validity with AVE was more than 0.54 and good construct reliability with Cronbach's alpha value was more than 0.83. More specifically, no violation of discriminant validity exists between social vision and sustainability of SESE instrument. The findings indicate that the SESE instrument met the psychometric characteristics from validity aspect and reliability to cultivate students' aspiration to become social entrepreneurs. The implications of the findings were discussed.
\end{abstract}

Keywords: Social entrepreneurial self-efficacy, social vision, sustainability, social entrepreneurship, ENACTUS, Malaysia.

\section{Introduction}

Social entrepreneurial self-efficacy (SESE) instrument emphasises on an individual's belief to handle a particular social problem that is appropriate to its needs. Generally, self-efficacy is referred as an important motivational construct that influences choices, goal settings, emotional reactions, effort, and determination in taking action (Stajkovic \& Luthans, 1998). Self-efficacy that will be discussed is in the context of students' social entrepreneurial tendency to develop community project in HEI through ENACTUS club.

ENACTUS is a non-profit organization (NGO) with a mission to produce students who have leadership quality with corporate and entrepreneurial image. This organization is used as a club for students' co-curriculum activities in 36 higher education institutions. Students who are members of the club are exposed to activities of developing marginalised community and the environment based on three-bottom-line, as well as trained to be leaders. Such exposure encourages students to have high self-efficacy towards their capability in pursuing their projects, as well as improves their background of study, resulting in an impact to the society.

Additionally, a strong belief in the capability of implementing community project must be supported with their understanding in social entrepreneurship field. Social entrepreneurship implementation in Malaysia is considered new, however this phenomenon has been present in the global stage for a long time (Urban, 2013). An in-depth understanding of social entrepreneurship is essential to promote an individual's interest, although it might take a considerable amount of time. This field could be understood through 3 conceptual differences, which are a) social entrepreneurship that focuses on process or behaviour; b) social enterprise that emphasizes on products of large or small industry; and c) social entrepreneurs who are founders and manufacturers. Social entrepreneurship creates innovative solution between social welfare that is unable to be satisfied by the government and private perspective assumption of risk (OECD, 2011). Consequently, production of good instrument validity will narrow the gap between the belief on capability and the goal setting on implementing social entrepreneurial activities.

\section{Literature Review}

\section{Social entrepreneurial self-efficacy (SESE)}

Generally, self-efficacy construct has been used in entrepreneurial business literature to predict an individual's tendency to become an entrepreneur. This has been agreed by Boyd and Vozikis (1994) in the 
general entrepreneurial context who found the existence of direct consequence on the relationship between selfefficacy and the implementation (behaviour) in developing the entrepreneurial determination and action. There should be trust on individual's capability to organize and implement the required steps to handle various situations (Bandura, 1977). In the research context, ENACTUS student self-efficacy level is evaluated based on the experience through process and the impact on implemented community development project. Self-efficacy is defined as the most effective forecaster in identifying an individual's performance result and it has been proven through previous studies (Bruch, Chesser \& Meyer, 1989). The vision to produce graduates with multi-tasking skills will be achieved if the academic and co-curriculum performance of ENACTUS students in HEI are high and balanced.

Self-efficacy prediction could ascertain an individual's capability and strength to deal with life obstacles and difficulties. An individual's possibility to act is dependent on his cognitive capability (Bandura, 1997; Bandura, 1986). This prediction emerges based on interactive information which relies upon cognitive learning theory (Bandura, 1997) with four main sources, a) vicarious experience (refers to ENACTUS students' experience from their involvement or others' observation on them in implementing community development project); b) mastery experience (refers to basic knowledge, skills and required experience in business management to achieve a goal that impacts a successful improvement of marginalised community standard of living); c) social persuasion (involves obvious or hidden influence towards the belief of implementing something based on different perceptions); and d) physiological state (refers to physiological condition specifically efficacy towards anxiety). Theory and research found that there are different ways of how an individual feels, thinks and acts (Schwarzer, 1993) accordingly depending on the situation. According to this theory, individuals have self system that enables them to control measure over their thought, feelings, motivations and actions (Bandura, 1986). Self-efficacy performance level consists of method and focus which are influenced by factors such as a) action in pursuing an option; b) effort dedicated to achieve a goal; c) persistence and commitment to persevere in facing obstacles and failures; d) resilience in dealing with difficulties; and e) stress and depression to meet environmental requirement.

These constructs are categorized into high and low levels. High self-efficacy represents efficient cognitive process including thinking and implementation in various situations. On the other hand, low selfefficacy is associated with characteristics of depression, anxiety and inferiority. In the context of cultivating social entrepreneurship interest, students who have high self-efficacy will have strong focus and good time management even though they study a tough major and actively volunteer in community development club. However, they do not excel in their selected field of study and lack initiative to join co-curriculum club especially volunteer activities. In the entrepreneurial self-efficacy context, Drnovšekt, Wincent and Cardon (2010) proved that there are three dimensions which influence a formation that involves i) entrepreneurial practices perspective (activities in starting up or expanding a business); ii) self-efficacy belief content (task or product of belief intention); and iii) entrepreneurial self-efficacy belief (positive or negative control belief).

Furthermore, Nga and Shamuganathan (2010) presented five social entrepreneurship dimensions that are closely related to social entrepreneurial self-efficacy, which are social vision, sustainability, social networking, innovativeness, and financial return. In particular, social vision is explained via a strong motivation to fulfil social needs. Social network dimension, either formal or informal, serves as a resource for advice, human resource, innovative ideas or capabilities, financial and emotional support. Meanwhile, social innovation dimension is created to build a sustainable solution platform through a combination of capabilities, products, processes and technologies. Sustainability and financial return include social values creation aspect, particularly any profit gained will be reinvested into the business. All dimensions are valid to measure the influence of personality agreeableness in Big Five Personality. However, this study emphasized only on two dimensions, namely social vision and sustainability, which are fundamental in examining the relationship of these items in the next sub-construct and subsequently suitable with the formation of SESE model, which are:

\section{a) Social vision}

Social vision pushes entrepreneurs ability to seek current opportunities objectively to become agents of social change (Barendsen and Gardner, 2004; Dees, 2001). The success of social entrepreneurship, either small or large scale, depends on the social vision that has been set. Social entrepreneurs often act as the driver in meeting social needs that are unable to be addressed by government sectors and public enterprise (London, 2008). A conviction in managing an enterprise depends on the entrepreneur's competency in managing a business. Other than that, vision setting requires social entrepreneurs with high and continuous commitment, those who are not easily influenced by market demand when creating social values (Nga \& Shamuganathan, 2010) especially of marginalised social development. A commitment is required to extend social issues which are generally felt through social entrepreneurs own emotion and responsibility. This research will measure social vision items among ENACTUS students by identifying whether they are reliable and valid as well as forming 
sub-construct sustainability relationship, and subsequently building the social entrepreneurial self-efficacy model.

\section{b) Sustainability}

Social entrepreneurs are the drivers of social change that fulfil the need of most people below the market pyramid that cannot be satisfied by business entrepreneurs or the government (Hart, 2005). The trust in social entrepreneurs' capability to create innovation will benefit the survival of marginalised community. Social entrepreneurial sustainability practices through responsibility and consideration in unifying visions are intended to encourage social entrepreneurs to be responsible in fulfilling the three-bottom-line target (Mort, Weerawardena \& Carnegie, 2003), which is interdependent in life eco-system. These practices could be strengthened if social entrepreneurs' self-belief towards their decisions are high. Every action is guided by ethical values, principal and commitment to maintain and protect long-term survival, as well as community and environmental rights consistently and sustainably. Social entrepreneurs always strive to create lasting social values by improving the community quality of life through creation of product and service innovation. Based on these contexts, ENACTUS students' experiences in implementing community development project will be measured by reliability and validity items, as well as social vision sub-construct relationship in building social entrepreneurial self-efficacy construct model.

\section{Social entrepreneurship}

This validity study focused on how effective is SESE in influencing ENACTUS students who ran small scale enterprises to become social entrepreneurs. Social entrepreneurship and business entrepreneurship differ in their intentions and profit target. However, the combination of both will result in a more effective social entrepreneurship management based on social creation values.

Various definitions related to social entrepreneurship have emerged since 1980s (OECD, 2010). Most definitions include processes, actions and organizations in producing social innovations. However, explorations on basic social entrepreneurial theory are still insufficient (Austin, Stevenson, \& Wei-Skillern, 2006; Mair \& Marti, 2006; Weerawardena \& Mort, 2006). Theories related to social entrepreneurship are mostly adopted from business entrepreneurship theory and adapted into social orientation. Social entrepreneurial self-efficacy is based on perceived behavioural control element in theory of planned behaviour (Ajzen, 1991) and is strengthened by social cognitive theory (Bandura, 1977) to identify the relationship between individual's belief and behaviour.

Table 1 Social entrepreneurship conceptual definition

activities that mobilize social enterprise with social orientation vision and gained profit will be reinvested into the business.

(General Entrepreneurship Monitor UK, 2006: 5)

defined as innovativeness, social values creating activities that may result from profits, businesses or government sectors.

Social entrepreneurship

(Wei-Skillern, Austin, Leonard \& Stevenson, 2007: 4)

defined as entrepreneurial activities that intend to provide innovative solutions to social problems that are unable to be addressed by government or private sectors, and aims at improving community life by encouraging social change.

(Organization for Economic Co-operation \& Development, 2010: 188)

play the role as social sector change agents by:

- setting goals to create and sustain social values (not limited to private values);

- identifying and aggressively pursuing new opportunities;

Social entrepreneurs

- engaging in continuous innovation process ;

- courageous in taking risks with limited resources; and

- showing high accountability towards innovation products.

(Dees, 1998: 4)

a business enterprise which is established for social purpose to address a particular social problem by creating social values while managing private sector enterprise with financial discipline, innovation and determination.

Social enterprise

(Alter, 2007: 12)

defined as an organization that utilizes business activities to achieve social visions.

(Social Enterprise UK, 2013: 5)

However, a clear understanding on social entrepreneurship requires initiatives from all parties including the individual to have an in-depth understanding and make comparison with business entrepreneurship as in Table 2. Business entrepreneurs expect high financial returns, skills and competencies to achieve their goals. On the other hand, social entrepreneurs rely on organization management as most of these entrepreneurs are highly motivated and dedicated. Innovations, to social entrepreneurs, are limited to three-bottom-line principals and have high impact. On the contrary, there is no limitation to business entrepreneurs to create innovations. Furthermore, business entrepreneurs are taking personal risks in their businesses. Social 
entrepreneurs on the other hand face the risk of community distrust and organization bad image if the set objectives are not achieved.

Table 2 Differences between entrepreneurial characteristics and social entrepreneurship.

\begin{tabular}{lll}
\hline Characteristics & Business entrepreneurship & Social entrepreneurship \\
\hline Vision & maximum profit. & $\begin{array}{l}\text { maximum social vision (positive impact on } \\
\text { community). } \\
\text { developing long-term capabilities. }\end{array}$ \\
$\begin{array}{l}\text { Focus } \\
\text { Product }\end{array}$ & short-term financial profit. & limited to ideas related to businesses' social vision. \\
Strength & strength in individual talent, skill, resource and & apart from individual talent, strength is displayed \\
& knowledge. & by intelligence and experience, as well as \\
Risk & entrepreneurs' and investors' responsibilities. & Entrepreneurs' responsibility.
\end{tabular}

Source: Venter, Urban and Rwigema (2008)

Knowledge, skill, competency, empathy and high motivation to become a social entrepreneur are requisites for an individual to set up an enterprise. Social enterprises functions differ from corporate and activists' social responsibilities. Most social enterprises start on a small scale. Beginning with community industries, they expand into local social firms, and next into social businesses, joint-venture companies, national level fair trade, and eventually into social entrepreneurships (Pearce, 2003). Social entrepreneurs' confidence to produce innovation is measured based on their impact to community and environmental development.

\section{Structural Equation Modelling (SEM)}

SEM has been established since late 1960s and has now become the dominant multivariate technique (Hair, Black, Babin \& Anderson, 2010). The same source explained that SEM cannot be put into practice without a strong basic theory particularly in building measurement and structural model. This analysis clarifies the correlation of model determinant, causation strength for cross-sectional data, and development of a modelling strategy. The study uses basic theory of planned-behaviour (Ajzen, 1991) and social cognitive theory (Bandura, 1977) to explore and validate social entrepreneurial self-efficacy.

Confirmatory Factor Analysis (CFA) needs to be performed to provide item values in sub-construct and to validate they meet the unidimensionality, validity and reliability requirements, before measurement and structural model is done.

The fundamental stage of SEM is to test measurement theory validation using CFA. The context of this research will look into the relationship between sub-constructs in SESE to variables (factor loading estimates) and sub-constructs to each other (construct correlation). Unidimensionality is understood through measurable indicator set and could be described by a construct base. The measurement is achieved ideally through weight factor loading for each item exceeding 0.7 (Hair et al., 2010) from established scales.

Subsequently, validity shall be measured in three stages through convergent validity, construct validity and discriminant validity. Convergent validity is reached when average variance extracted (AVE) value is more than 0.5 (Fornel \& Larcker, 1981) with standardized factor loading minimum value of each item equal or more than 0.60 (Hair et al., 2010; Bagozzi \& Yi, 1988). Another indicator for convergent validity is construct reliability where Cronbach's alpha value for each construct should exceed 0.70 to maintain internal consistency. Construct validity on the other hand should be at least one absolute fit index and one incremental fit index (Hair et al., 2010). However, p-value should be significant using type I error of 0.50. The Relative Chi-Square value must be less than 5.0 (Marsh \& Hocevar, 1985).

For absolute fit index, root mean square error of approximation (RMSEA) is below 0.08 (Brown \& Cudeck, 1993) and goodness-of-fit index (GFI) is more than 0.95 (Hair et al., 2010). As for incremental fit index, comparative fit index (CFI) is more than 0.90 (Bentler, 1990). Additionally, parsimony fit index is reached when adjusted goodness-of-fit index is more than 0.90 , which reflects good model fit. Meanwhile, discriminant validity is used to compare that the construct is truly distinct from other constructs. It is used to examine the interconstruct covariance as correlation. This validity is reached with correlation differences between two sub-constructs are less than 0.90 ( $\mathrm{r}<0.90)$. When each sub-construct has met the compliance, empirical analysis is carried out to identify the relationship between SESE and ENACTUS students' confidence level.

\section{Research Objectives}

This descriptive research intends to test the validity of social entrepreneurial self-efficacy (SESE) instrument, namely social vision and sustainability. The objective of this study was to verify the reliability and validity of the social entrepreneurial self-efficacy instrument. The research hypothesis predicts that $\mathrm{Ha}_{1}$ : There is a relationship between social vision and sustainability sub-constructs at higher SESE. 


\section{Methodology}

The purpose of this research is to obtain reliability and validity of social entrepreneurial self-efficacy (SESE). Study respondents were selected using proportional stratified sampling based on university category involving 321 ENACTUS students in all higher learning institutions. The researcher distributed questionnaires by having a scheduled meeting with ENACTUS students at each university. Items in the questionnaire were adapted and modified from SESE instrument by Urban (2013) which consisted 14 items. The instrument was divided into sub-constructs, namely social vision and sustainability where each sub-construct represented 7 items. Each item was measured based on 5 point Likert scale starting with 5 meaning 'strongly agree', 4 meaning 'agree', 3 meaning 'moderately agree', 2 meaning 'disagree', and 1 meaning 'strongly disagree'.

The collected data were analyzed using SEM analysis on AMOS software (version 21). This study presented only the data preparation stage, namely Confirmatory Factor Analysis (CFA). CFA was conducted beforehand to verify items were suitable and sub-constructs could be connected to form SESE model. Questionnaires were distributed to ENACTUS students, and after the analysis was completed, only 9 items were identified as valid match for SESE model.

\section{Findings}

Confirmatory factor analysis (CFA) using SEM involved statistics to accurately measure the internal consistency and construct validity of theoretical factor matches the actual data. Content validity on the suitability of items was obtained from expert's opinion beforehand, followed by empirical study using CFA analysis. There are three procedures that must be complied with when carrying out CFA, namely model fit, convergent validity and construct reliability.

There are 14 items representing social vision and sustainability sub-constructs based on the original hypothesis model (Figure 1). Although factor loading value for each item was more than 0.50, this model did not meet the fit indices requirement. To check the suitability (fit) of the measurement model, the analysis referred to the fitness index and the literature supporting it. At the beginning stage, the model did not fit well with Chi Square/Degrees of Freedom (CMIN/DF) value of more than 5.0. On the other hand, Root Mean Square of Error Approximation (RMSEA) was below 0.08, while Comparative Fit index (CFI), Tucker-Lewis index (TLI) and Goodness of Fit Index (GFI) were achieved with index value greater than 0.90 . Therefore, the lowest loading items need to be removed one item at a time until all items have reached the model fit requirement.

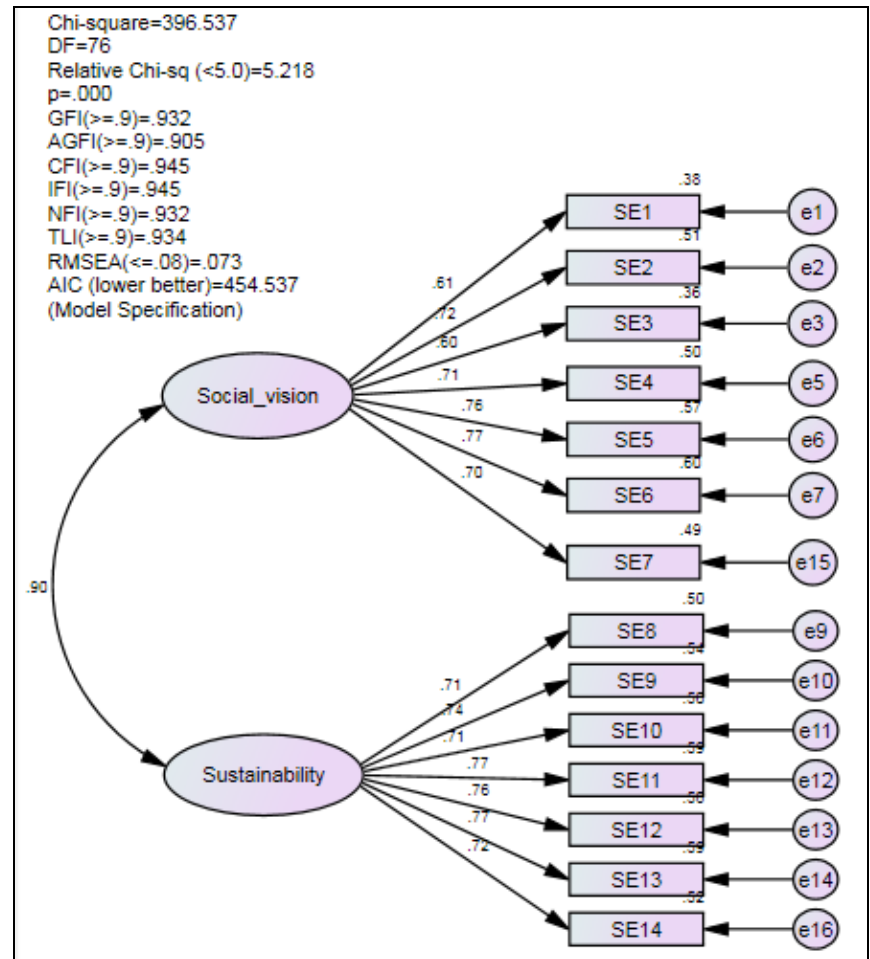

Figure 1 Hypothesized model of social entrepreneurial self-efficacy (SESE)

The review process found that 4 items representing social vision and 3 items representing sustainability met the unidimensionality requirement perfectly as recommended by Hair et al., (2010) where factor loading value was more than 0.70 (Table 3 ), hence matching a good model fit. 
Table 3: Result of unidimensionality procedure

\begin{tabular}{llllll}
\hline Sub-construct & $\begin{array}{l}\text { Items before } \\
\text { remove }\end{array}$ & $\begin{array}{l}\text { Items after } \\
\text { remove }\end{array}$ & Revised items & Mean & $\begin{array}{l}\text { Standard } \\
\text { Deviation }\end{array}$ \\
\hline Social vision & 7 items & 4 items & SESE2 & 3.68 & 0.728 \\
& & & SESE4 & 3.60 & 0.785 \\
& & SESE5 & 3.58 & 0.751 \\
& & & SESE6 & 3.74 & 0.759 \\
Sustainability & \multirow{2}{*}{7 items } & 3 items & SESE10 & 3.65 & 0.764 \\
& & & SESE12 & 3.58 & 0.783 \\
& & & SESE13 & 3.60 & 0.722 \\
\hline
\end{tabular}

The first step was satisfied when the fit indices requirement (Relative Chi-Square, <0.50; fit index, $>0.90$; RMSEA, <0.08) and factor loading values of more than 0.7 were achieved. The second step in this measurement model was to evaluate the convergent validity, construct reliability and discriminant validity. The results showed that the value of AVE was greater than 0.50 (social vision $=0.545$, sustainability $=0.594$ ) and construct reliability was more than 0.80 (social vision $=0.829$, sustainability $=0.876$ ). Thus, the SESE instruments for 7 items demonstrated good convergent validity, reliability, as well as internal consistency. A minimum of 3 items, or ideally 4 items are required to represent suitable construct domain in illustrating a particular theory (Hair et al., 2010). For this research, there are 4 items representing social vision sub-construct, and 3 items representing sustainability sub-construct.

Table 4: Results of CFA for convergent validity and construct reliability

\begin{tabular}{|c|c|c|c|c|c|}
\hline Sub-construct & Item & $\begin{array}{l}\text { Internal reliability } \\
\text { Cronbach alpha } \\
\text { (above 0.70) }\end{array}$ & $\begin{array}{l}\text { Factor loading } \\
\text { (above 0.70) }\end{array}$ & $\begin{array}{l}\mathrm{CR}^{\mathrm{a}} \\
\text { (above 0.70) }\end{array}$ & $\begin{array}{l}\mathrm{AVE}^{\mathrm{b}} \\
\text { (above 0.5) }\end{array}$ \\
\hline \multirow{4}{*}{$\begin{array}{l}\text { Social vision } \\
\text { (4 items) }\end{array}$} & SESE2 & \multirow{4}{*}{0.828} & 0.70 & \multirow{4}{*}{0.829} & \multirow{4}{*}{0.545} \\
\hline & SESE4 & & 0.72 & & \\
\hline & SESE5 & & 0.80 & & \\
\hline & SESE6 & & 0.73 & & \\
\hline \multirow{3}{*}{$\begin{array}{l}\text { Sustainability } \\
\text { (3 items) }\end{array}$} & SESE10 & \multirow{3}{*}{0.810} & 0.74 & \multirow{3}{*}{0.876} & \multirow{3}{*}{0.594} \\
\hline & SESE12 & & 0.80 & & \\
\hline & SESE13 & & 0.77 & & \\
\hline
\end{tabular}

Note:

All t-values are significant at 0.001 level.

${ }^{\mathrm{a}}$ Construct reliability $=$ (square of the summation of the factor loadings $) /\{$ (square of the summation of the factor loadings) + (square of the summation of the error variances) $\}$

${ }^{\mathrm{b}}$ Average variance extracted $=$ (summation of the square of the factor loadings $) /\{$ (summation of the square of the factor loadings) + (summation of the error variances) $\}$

The result indicated that discriminant validity of SESE measurement model is valid (Table 5). The correlations between two sub-constructs with $\mathrm{r}$ was 0.80 and below 0.90 (Fornell \& Lacker, 1981; Hair et al., 2010), confirming the discriminant validity of the instrument. This study had achieved the fitness indexes level in terms of construct validity compliance. Construct measurement of SESE was obtained. Discriminant validity was implemented to ensure that there was no redundant item in the measurement model. Besides, there was no high correlation or multicollinearity existed because two latent exogenous constructs which were correlated with $\mathrm{r}=0.80$ were less than 0.90 .

Table 5: Correlation matrix between sub-constructs

\begin{tabular}{lll}
\hline Sub-construct & SV & ST \\
\hline (1) Social vision (SV) & 1.00 & \\
(2) Sustainability (ST) & 0.80 & 1.00 \\
\hline
\end{tabular}

After revising the model, 7 fitness index criteria should be fulfilled as shown in Table 6. Finally, SESE consisted of two sub-constructs with 7 items, namely social vision and sustainability.

Table 6: Current fit and suggested level criteria of SESE

\begin{tabular}{|c|c|c|c|c|c|c|c|c|}
\hline Index fit & CMIN & $\begin{array}{l}\text { CMIN/DF } \\
<5.00\end{array}$ & $\begin{array}{l}\mathrm{P} \\
<0.05\end{array}$ & $\begin{array}{l}\text { GFI } \\
>0.90\end{array}$ & $\begin{array}{l}\text { NFI } \\
>0.90\end{array}$ & $\begin{array}{l}\text { CFI } \\
>0.90\end{array}$ & $\begin{array}{l}\text { TLI } \\
>0.90\end{array}$ & $\begin{array}{l}\text { RMSEA } \\
<0.08\end{array}$ \\
\hline Source & $\begin{array}{l}\text { Tabachnik \& } \\
\text { Fidell (2013) }\end{array}$ & $\begin{array}{l}\text { Marsh \& } \\
\text { Hocevar } \\
(1985)\end{array}$ & $\begin{array}{l}\text { Pallant } \\
(2011)\end{array}$ & $\begin{array}{l}\text { Bentler } \\
(1990)\end{array}$ & $\begin{array}{l}\text { Chau } \\
(1997)\end{array}$ & $\begin{array}{l}\text { Segars \& } \\
\text { Grover } \\
(1993)\end{array}$ & $\begin{array}{l}\text { Bentler \& } \\
\text { Bonett } \\
(1980)\end{array}$ & $\begin{array}{l}\text { Brown \& } \\
\text { Cudeck } \\
(1993)\end{array}$ \\
\hline $\begin{array}{l}\text { Current } \\
\text { fit }\end{array}$ & 38.014 & 2.924 & 0.000 & 0.967 & 0.962 & 0.974 & 0.959 & 0.078 \\
\hline
\end{tabular}


Figure 2 below shows the results of the two-factor measurement model of social entrepreneurial selfefficacy. The chi-square of goodness-of-fit indexes value obtained was 38.014. All fit indices types were employed and acceptable by recommended values with GFI (0.967), CFI (0.974), NFI (0.962), TLI (0.959) more than 0.90, and RMSEA (0.078) less than 0.08. Meanwhile, the revised model was achieved as it passed all the criteria values and indicated that the model fit the data.

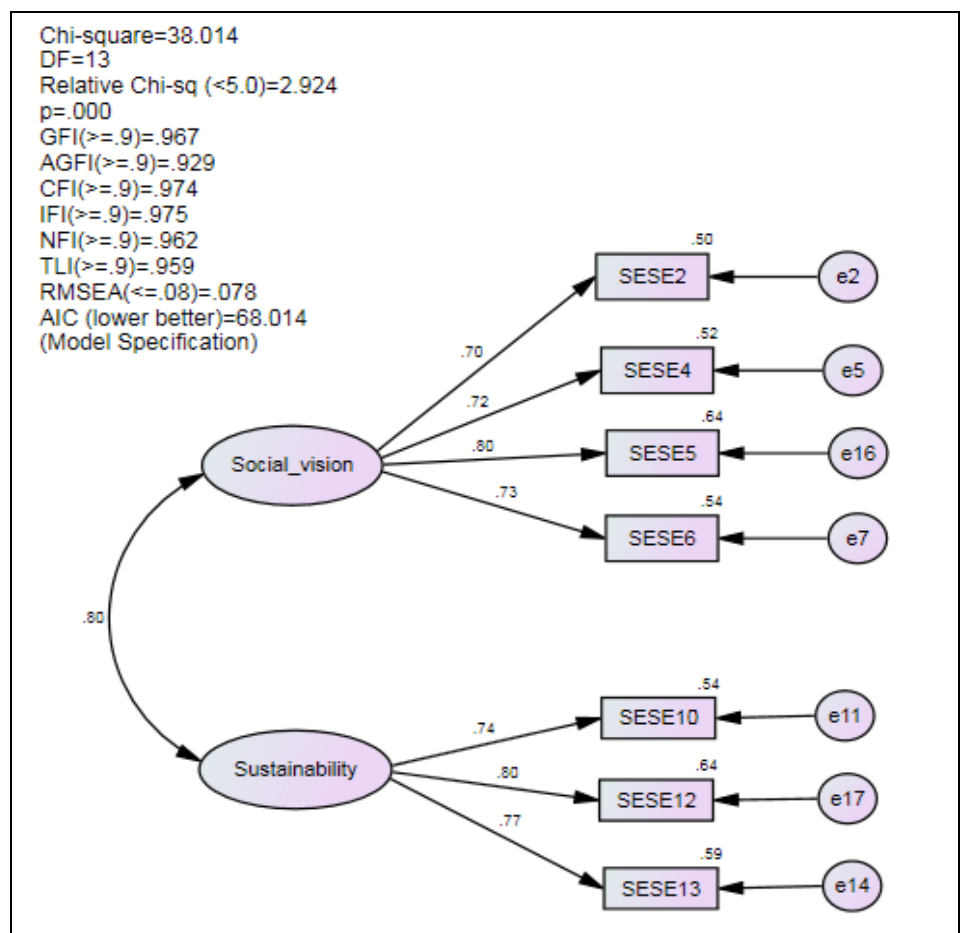

Figure 2 Measurement model of social entrepreneurial self-efficacy (SESE) sub-construct (social vision and sustainability) using CFA

The inter-factor correlation was $r=0.80$, which substantiated the research hypothesis $\left(\mathrm{Ha}_{1}\right)$ and supported the relationship significantly between two sub-constructs or sub-dimension (social vision and sustainability). The loading range was between 0.70 and 0.80 . This result was achieved after considering the modification index (MI). The construct validity for social entrepreneurial self-efficacy was supported. The final result showed only 7 self-efficacy items fit the model and accomplished the psychometric value, particularly the social entrepreneurial self-efficacy index, on becoming a social entrepreneur among the new young generation.

\section{Discussion}

Generally, self-efficacy research is mostly analyzed from the behaviour aspect towards career (Betz, 2000). Self-efficacy plays an important role in deciding students' aspirations that are measured through their confidence and capability to set sustainable social vision for the social entrepreneurial activities that they pursue. ENACTUS students' determination and successes in building community project are influenced by their high level of self-efficacy.

The findings revealed social vision and sustainability items met unidimensionality requirement as social entrepreneurial self-efficacy (SESE) items measurement. Confirmatory Factor Analysis (CFA) showed that the 7 items were loaded into two dimensions of SESE after forced extraction. All the items fitted very well with value of more than 0.70 . Meanwhile, convergent validity had shown high weighting factor for two subconstructs were higher than 0.70 , AVE value for social vision and sustainability was greater than 0.50 , and CR value for each sub-construct was more than 0.80. All the evidences supported and met the level recommended by Hair et al., (2010) with the sample size exceeded 300 and the significance level at p-value of 0.00 , which determined the strength of the correlation item of latent variable in a CFA analysis.

Meanwhile, it was also found that the correlation ( $r$ ) between two sub-constructs for discriminant validity was less than 0.90 and met the criteria set as recommended by Fornell and Larcker (1981) and Hair et al., (2010). All sub-constructs showed high construct validity as the model showed good fit with all the criteria, namely RMSEA less than 0.08 (Byrne, 2010), relative Chi-Square less than 5.0 (Bentler, 1990), and CFI, NFI and GFI more than 0.90 (Schumacker \& Lomax, 2010; Chau, 1997), which are acceptable to determine the 
validity of the constructs. Furthermore, reliability index of the items exceeded 0.80 , which indicated an acceptable, high and consistent index as recommended by DeVellis (2012).

The finding indicated that ENACTUS students' social entrepreneurial self-efficacy was shaped by social vision and sustainability dimension (Figure 2). It verified that there were four items representing a) strongly committed to a social vision; b) clearly able to identify social need; c) able to create a social vision; and d) strongly motivated to defend social need, that contributed to the formation of social vision dimension. Meanwhile, only 3 items on sustainability dimension contributed to the formation of sustainability dimension, which were a) improved long-term social need; b) promote a balance of economic, social and environmental concerns; and c) promote a balance between social mission and social value. Therefore, not all selected items met the model fit requirements to represent SESE in the Malaysian context. This is in contrary to the study by Urban (2013) which found that all items had high influence in forming students' self-efficacy, which was the basis for encouraging social entrepreneurship in South Africa. When all items had been analyzed, verified and matched with SESE model, researchers need to subsequently analyze measurement model and structural model to resolve subsequent hypothesis that are related to the relationship or comparison between SESE and other constructs.

\section{Conclusion}

The Confirmatory Factor Analysis (CFA) is the first step in preparing Structural Equation Modelling (SEM) data. CFA was used to test the individual construct of social entrepreneurial self-efficacy items. The purpose is to test for model fit, convergent validity, and construct reliability. Model fit test found that factor loading was greater than 0.50 and achieved some fit indices (Relative Chi-Square, fit index and RMSEA). Convergent validity was achieved when AVE was greater than 0.50 and construct reliability was greater than 0.70 . Meanwhile, CFA was carried out using measurement model through discriminant validity analysis. This assessment found that the correlation value between social vision and sustainability was less than 0.90 , which also indicated there was no violation in SESE instrument. The social entrepreneurial self-efficacy dimension was described by the two sub-constructs; social vision and sustainability. A total of 7 items achieved model fit, good convergent validity, construct reliability and discriminant validity (good internal consistency). Social entrepreneurial self-efficacy instrument was adopted to measure the level of beliefs on ENACTUS' students in Malaysia. This study presented strong evidence to support the validity of the instrument.

From practical perspectives, SESE instrument was established to measure an individual's confidence and capability to pursue social entrepreneurship as a career. Moreover, it also contributed to new type of business development process. Organization or non-government organization (NGO) could use this instrument to seek qualified candidates and meet social entrepreneurship requirements suitable with their confidence and motivation when faced with failures. They will be exposed to new skills, uncertain environment and capability to obtain resources in an increasingly challenging competition, especially in managing small scale social enterprise.

In addition, SESE instrument is a reliable tool to determine self-efficacy of social entrepreneurial education and a guide to curriculum policy makers specifically at HEIs level. Students will be able to develop the potential of SESE profiles based on various academic backgrounds. Social vision and sustainability dimensions are used as a basic mechanism in designing new and existing social entrepreneurial pedagogical curriculum. This is to ensure that success of the teaching and training program will cultivate high social entrepreneurial capability among students when implementing marginalised community project. Therefore, this instrument could be applied dynamically in understanding a student's process to become a social entrepreneur.

\section{References}

[1]. Ajzen, I., The Theory of Planned Behavior. Organizational Behavior and Human Decision Processes, 50, $1991,179-211$.

[2]. Alter, K., Social enterprise typology, 2007, Retrieved October 29, 2012 from http://www.virtueventures.com/files/setypology.pdf

[3]. Austin, J., Stevenson, H. \& Wei-Skillern, J., Social and commercial entrepreneurship: same, different, or both? Entrepreneurship: Theory \& Practice, 30(1), 2006, 1-22.

[4]. Bagozzi, R.P. \& Yi, Y., On the evaluation of structural equation models. Academy of Marketing Science, 16 (1), $1988,74-94$.

[5]. Bandura, A., Self-efficacy: towards a unifying theory of behavioural change. Psychological Review 84, 1977, 191-215.

[6]. Bandura, A., Social foundations of thought and action: a social cognitive theory (Englewood Cliffs, New Jersey: Prentice-Hall, 1986).

[7]. Barendsen, L. \& Gardner, H., Is the social entrepreneur a new type of leader? Leader to Leader 2004, 34, 2004, 43-50.

[8]. Bentler, P.M., Comparative fit indexes in structural models. Psychological Bulletin 107 (2), 1990, $238-246$.

[9]. Byod, N. G. \& Vozikis, G. S., The influence of self-efficacy on the development of entrepreneurial intentions and actions. Entrepreneurial Theory \& Practices 18 (4), 1994, 63-78.

[10]. Browne, M.W. \& Cudeck, R., Alternative ways of assessing model fit. In Testing Structural Equation Models, eds K.A Bollen \& J.S. Long, (Sage Publications, Beverly Hills, CA, 1993), 136-162.

[11]. Bruch, M., Chesser, E. S. \& Meyer, V., The role of evaluative self-schemata in cognitive processing and performance: the impact on self-efficacy, self-evaluation and task outcome. Scandinavian Journal of Behavior Therapy 18, 1989, 71-84.

[12]. Byrne, B.M. (2010). Structural Equation Modeling with AMOS: basic concepts, applications and programming, $2^{\text {nd }}$ Ed., Multivariate Application Series (Taylor and Francis Group, New York, 2010). 
[13]. Chau, P., Re-examining a model for evaluating information center success using a Structural Equation Modeling approach. Decision Science, 28(2), 1997, 309-333.

[14]. Dees, J.G., The meaning of social entrepreneurship, 1998, Retrieved March 31, 2012 from http://www.fntc.info/ files/documents/ The\%20meaning\% 20of\%20Social\%20Entreneurship.pdf

[15]. Dees, J. G., The meaning of social entrepreneurship, 2001, Retrieved June 31, 2014 from http://www.fuqua.duke.edu/centers/case/documents/dees SE.pdf

[16]. DeVellis, R.F., Scale development: theory and applications. ${ }^{\text {rd }}$ Ed., (Sage Publications, Thousand Oaks, C.A., 2012)

[17]. Drnovšek, M., Wincent, J. \& Cardon, S. M., Entrepreneurial self-efficacy and business start-up: developing a multi-dimensional definition. International Journal of Entrepreneurial Behaviour \&Research, 16(4), 2010, 329-348.

[18]. Fornell, C. and Larcker, D.F., Evaluating Structural Equation Models with unobservable variables and measurement error. Journal of Marketing Research, 18 (1), 1981, 39-50.

[19]. General Entrepreneurship Monitor, Adult population survey. (Global Report on Entrepreneurship, Babson College, 2009: 2011).

[20]. General Entrepreneurship Monitor UK. (GEM 2006). Social entrepreneurship monitor. ed Harding, R. London Business School: Regent's Park.

[21]. Hair, J.F., Black, B., Babin, B., Anderson, R.E., and Tatham, R.L., Multivariate data analysis: a global perspective. 7th Ed., (Pearson Education Inc. New Jersey, 2010)

[22]. Hart, S. L., Innovation, creative destruction and sustainability. Research Technology Management, 45(5), 2005, 21-33.

[23]. London, M., Dual roles for corporate social responsibility and social entrepreneurship. Organizational Dynamics, 37(4), 2008, 1078- 1106.

[24]. Mair, J. \& Marti, I., Social entrepreneurship research: A source of explanation, prediction and delight. Journal of World Business, 41, 2006, 32-44.

[25]. Marsh, H. W. \& Hocevar, D., Application of confirmatory factor analysis to the study of self-concept: First- and higher order factor models and their invariance across groups. Psychological Bulletin, 97, 1985, 562-582.

[26]. Mort, G.S., Weerawardena, J. and Carnegie, K., Social entrepreneurship: towards Conceptualisation. International Journal of Nonprofit and Voluntary Sector Marketing, 8 (1), 2003, 76-88.

[27]. Nga, J.K.H. \& Shamuganathan, G., The influence of personality traits and demographic factors on social entrepreneurship start up intentions. Journal of Business Ethics, 95(2), 2010, 259-282.

[28]. OECD (Organization for Economic Co-operation \& Development), Chapter 5, (SMEs, Entrepreneurship and Innovation, 2010), $185-215$

[29]. OECD (Organization for Economic Co-operation \& Development), Fostering innovation to address social challenges, Workshop Proceedings, 2011, Retrieved June 31, 2013 from http://www.oecd.org/science/inno/ 47861327.pdf

[30]. Pearce, J., Social enterprise in anytown (London: Calouste Gulbenkian Foundation, 2003).

[31]. Schumacker, R. and Lomax, R.G., A beginner's guide to Structural Equation Modeling, 3rd Ed., (Routledge, Taylor andFrancis Group, New York, 2010)

[32]. Schwarzer, R., Measurement of perceived self-efficacy. Psychometric scales for cross-cultural research. (Berlin, Germany: Freie Universität Berlin, 1993).

[33]. Social Enterprise UK, The people's business: the state of social enterprise survey, 2013: 16.

[34]. Stajkovic, A. D., \& Luthans, F., Self-efficacy and work-related performance: A meta-analysis. Psychological Bulletin, 124(2), 1988, 240-261

[35]. Urban, B., Social entrepreneurship in an emerging economy: a focus on the institutional environment and social entrepreneurial self-efficacy. Managing Global Transitions, 11 (1), 2013, 3-25.

[36]. Venter, R., Urban, B. \& Rwigema, H., Entrepreneurship theory in practice (Cape Town: Oxford University Press, 2008).

[37]. Weerawardena, J. \& Mort, G. S., Investigating social entrepreneurship: a multidimensional model. Journal of World Business, 41(1), 2006, 21-35.

[38]. Wei-Skillern, J., Austin, J., Leonard, H. \& Stevenson, H., Entrepreneurship in the social sector (Thousand Oaks: Sage Publications, 2007). 